\title{
Ethnologies
}

\section{Catherine Ferland. Bacchus en Canada. Boissons, buveurs et ivresses en Nouvelle-France. (Québec, Les editions du Septentrion, 2010. Pp 9-413, ISBN 978-2-89448-603-0)}

\section{Genia Boivin}

Volume 35, numéro 1, 2013

URI : https://id.erudit.org/iderudit/1026465ar

DOI : https://doi.org/10.7202/1026465ar

Aller au sommaire du numéro

Éditeur(s)

Association Canadienne d'Ethnologie et de Folklore

ISSN

1481-5974 (imprimé)

1708-0401 (numérique)

Découvrir la revue

Citer ce compte rendu

Boivin, G. (2013). Compte rendu de [Catherine Ferland. Bacchus en Canada.

Boissons, buveurs et ivresses en Nouvelle-France. (Québec, Les editions du

Septentrion, 2010. Pp 9-413, ISBN 978-2-89448-603-0)]. Ethnologies, 35(1),

207-210. https://doi.org/10.7202/1026465ar d'utilisation que vous pouvez consulter en ligne.

https://apropos.erudit.org/fr/usagers/politique-dutilisation/ 
This collection accurately portrays the range of interests and concerns among the Gaelic research community. I recommend this book as a starting point for anyone new to such issues to begin research; however, it is clear that the highly specific nature of this publication would indicate that its intended audience lies among Celticists, historians, and policy planners interested in Scottish Gaelic and its revitalization. The inclusion of the longer, plenary papers was an excellent decision, offering some variety in length and depth of the articles. The most significant strength of the collection is its detailed research in regard to primary and archival sources, which would be particularly useful to anyone who shares similar research interests to these studies.

Ian Hayes

Memorial University of Newfoundland

Catherine Ferland. Bacchus en Canada. Boissons, buveurs et ivresses en Nouvelle-France. (Québec, Les editions du Septentrion, 2010. Pp 9-413, ISBN 978-2-89448-603-0)

There are cultural activities that are so integrated in the 'natural and ordinary' path of life that one does not even notice them anymore. Yet these activities are to be much more complex than they first appear. Drinking is one of them. On one hand, drinking carries strong negative associations. Abuse and loss of control is connected with alcoholism. Some religious and cultural groups condemn it entirely. On the other hand, in other cultural and religious groups, such as New France's French-Canadians, it occupies an important social place.

Drinking in New France's $17^{\text {th }}$ and $18^{\text {th }}$ centuries had physical, social and spiritual functions, which makes it an important cultural element. First, drinking was an important aspect of eating with the family. In addition, it was seen as preventing some diseases and 
helping curing others. (14) Socially, drinking was associated with the idea of conviviality. Set in a specific prescribed social frame, it promoted a certain feeling of belonging as drinking together demonstrated you shared similar values. (16) Alcohol consumption was also a highly gendered activity as it was generally reserved for men. (17) Finally, drinking had a spiritual function in New France because of its association with the Eucharistic ritual in Catholicism. In this light, drinking for French-Canadians was strongly integrated into their 'ordinary' lives, and Dr. Catherine Ferland brings to light the multifaceted role alcohol had in the colony.

Bacchus en Canada. Boissons, buveurs et ivresses en Nouvelle-France, presents a study of the activity of drinking and its adaptation in the new cultural environment of $17^{\text {th }}$ and $18^{\text {th }}$ centuries New France. The author's foreword sets a mise en scène of the era studied in this publication. In the introduction, Ferland offers a detailed review of the sources available about alcohol and alcohol consumption. Although the corpus on drinking in New France is limited, the author was able to dig up numerous historical and anthropological documents about this activity from France, England and the United States. Ferland based her research on printed material such as books and articles but also on manuscripts, old newspapers, law records documenting the public effect of alcohol, notary papers keeping a record of private consumption and finally archeological sources related to artifact findings connected to drinking.

The book is organized in three parts. The first part studies the type of drinks that were produced, imported and distributed in New France. Chapter 1 deals with the attempts at producing wine in the colony, especially for spiritual purposes, and the wine makers. Because the wine production was not a success in Canada, the beer production in private, ecclesiastic and state breweries are also introduced in this first part. Ferland also examines cider and spruce beer production as well as the brewer trade during this period. Chapter 2 is constituted by the importation of alcoholic beverages that could not be produced in Canada. These importations included wine from France (mostly red, brandy, cognac, aromatic liqueurs) popular in the elite classes, and rum from the Caribbean. Finally, the third chapter examines the market, transportation, distribution and stockings of alcoholic beverages in different social groups of the colony. This first part of 
the book presents a more historical-oriented approach to the study of drinks and drinking.

Part 2 of the book deals with the drinkers and it is probably the most valuable for the field of folklore for its examination of the ways of drinking in different social groups: the working class, the elite and the sailors and soldiers. Chapter 4 presents the uses and functions of the activity of drinking of working class, who consumes mostly beer, wine or brandy in inexpensive containers. Ferland demonstrates the links between alcohol and beliefs related to health as well as its function in popular religion, in calendar and life cycles' celebrations, and in economical exchanges between people. The author looks at alcohol consumption of men and women in urban and rural milieux and at home. Public drunkenness, alcoholism and criminal activities are examines as well in this chapter.

The fifth chapter consists of a similar study but of the colonial elite. Ferland shows that their choice of drinks, mostly wine and rarely beer, drank in more or less refined glasses, clearly marks their desire of distinguishing themselves from the working class. Abuse of alcohol happens generally in private spheres and is more discreet than with the working class. The nobles tend to keep their beverages in wine cellars or vaults, built specially for that purpose.

The sixth chapter proposes a study of the drinking habits of the sailors and soldiers. Because these people are generally far from their own people and forced to form a temporary community, their drinking activities are based on different mechanisms. Furthermore, it represents one of the rare entertainments they can enjoy. Thus, drinking is closely associated with their identities. Sailors cannot preserve water the same way as alcohol during their long travels. Beverages are generally rationed, like in the army, and sailors don't hesitate to experiment with them as Ferland shows in the recipes she found of the $17^{\text {th }}$ and $18^{\text {th }}$ centuries. Sailors drink also to avoid Scurvy, seasickness and warm-up the body. Soldiers also receive rationed alcohol, although beer tends to be more popular in this group. It is common to give them alcohol before battles or as a way to help the sick or the injured. Like in sailing, the army has a strict hierarchy and taste are generally contrasted: sailors preferring sweet liquids while captain keeping the finer wines for their tables; soldiers drink 
beer and brandy while officers will prefer fine wines and liquors. In both groups and their social classes, being able to drink a lot without loosing their dignity is a sign of virility.

The third part of the book focuses on Aboriginal drinkers and their alcohol consumption. Chapter 7 examines the introduction of alcohol in the exchanges between the Natives, the Europeans and the trappers in fur trades as well as the economical and political impact of the trade on the colony. Chapter 8 deals with the consequences of the Natives' alcohol consumption and tries to explain it. The French brought with them a liquid that was completely unknown to the Natives. These Natives did not drink socially or because they enjoyed the taste but with intoxication as a goal. Ferland sees this as a direct result of the anxiety cause by the proximity of White men, by their territory being evaded and by the deconstruction of their traditional social structures. The author proposes as well a second, more positive, interpretation. In a group where dream is seen as a beneficial state, drunkenness can be explained as a way to access the spirit world. In that sense, Amerindians' overconsumption is reinterpreted as a resistance to European invasion. The Amerindian history and situation is complex and while Ferland's theory might not please all readers, it certainly proposes a reading where Natives are not simple victims but are taking active part in their history.

Although Catherine Ferland examines the complexity of drinking in the $17^{\text {th }}$ and $18^{\text {th }}$ centuries New France, her research is still relevant today: North American society encourages the consumption of alcohol in television, films, and advertisements, as well as in many cultural and sport events. Paradoxically, the same society denounces the abuse of alcohol and condemns alcoholism. The large corpus of illustrations adds to Ferland's text. However, it would have been interesting to know the reason why she chose the artist Sophie Moisan to produce the colored illustrations as opposed to another artist. Overall, Ferland's book provides an excellent background in this field of studies for both the academics and the non-specialists.

Genia Boivin University of Alberta 